CASANOVA IN THE ENLIGHTENMENT

From the Margins to the Centre 
THE UCLA CLARK MEMORIAL LIBRARY SERIES 


\section{CASANOVA IN THE ENLIGHTENMENT}

\section{FROM THE MARGINS TO THE CENTRE}

Edited by Malina Stefanovska

Published by the University of Toronto Press in association with the UCLA Center for Seventeenth- and Eighteenth-Century Studies and the William Andrews Clark Memorial Library 
(C) The Regents of the University of California 2021

utorontopress.com

Printed in the U.S.A.

ISBN 978-1-4875-0664-3 (cloth)

ISBN 978-1-4875-3458-5 (EPUB)

ISBN 978-1-4875-3457-8 (PDF)

\section{Library and Archives Canada Cataloguing in Publication}

Title: Casanova in the Enlightenment : from the margins to the centre / edited by Malina Stefanovska.

Names: Stefanovska, Malina, editor.

Series: UCLA Clark Memorial Library series ; 30.

Description: Series statement: UCLA Clark Memorial Library series ;

30 | Includes bibliographical references and index.

Identifiers: Canadiana (print) 20200253387 | Canadiana (ebook)

20200253514 | ISBN 9781487506643 (cloth) | ISBN 9781487534585

(EPUB) | ISBN 9781487534578 (PDF)

Subjects: LCSH: Casanova, Giacomo, 1725-1798. Mémoires.

Classification: LCC D285.8.C4 C37 2021 | DDC 940.2/53092 - dc23

This book has been published with the help of a grant from the UCLA Center for Seventeenth- and Eighteenth-Century Studies.

University of Toronto Press acknowledges the financial assistance to its publishing program of the Canada Council for the Arts and the Ontario Arts Council, an agency of the Government of Ontario.

Canada Council for the Arts
Conseil des Arts du Canada

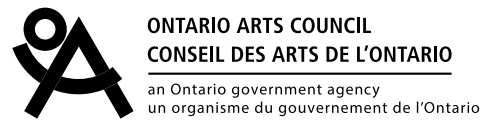

